\title{
29. Water security: Converging toward common understanding through quantification
}

\author{
Jonathan Lautze \\ International Water Management Institute, Sri Lanka \\ Herath Manthrithilake \\ International Water Management Institute, Sri Lanka
}

\begin{abstract}
Water security has come to assume an increasingly prominent position in the international water and development community in recent years. Staff at the World Bank have explained that water security is critical for growth and development (Grey and Sadoff 2007). The importance of water security for the sustainable development of countries like China has been recognised nationally (Liu et al. 2007). Water security has been at the heart of high-profile negotiations on, for example, a Cooperative Framework Agreement in the Nile Basin (WaterLink 2010). Finally, academia and other development actors have also emphasised the concept (Briscoe 2009).
\end{abstract}

\section{What is missing?}

Despite the elevated status that the term has increasingly acquired in policy documents and development discourse, the concept of water security remains largely unquantified. There are several benefits to translating water security into numerical terms. First, it can encourage clarity and common understanding of a concept around which there currently exists substantial ambiguity. Second, it can help to foster discussion and debate on scales and thresholds for evaluating the presence, absence or degree of water security. Third, it can help to assess the extent to which the concept is really being achieved on the ground in different locations. In a recent paper we devised an index that quantifies water security at a country level in order to encourage a more concrete understanding of the term (Lautze and Manthrithilake 2012). 


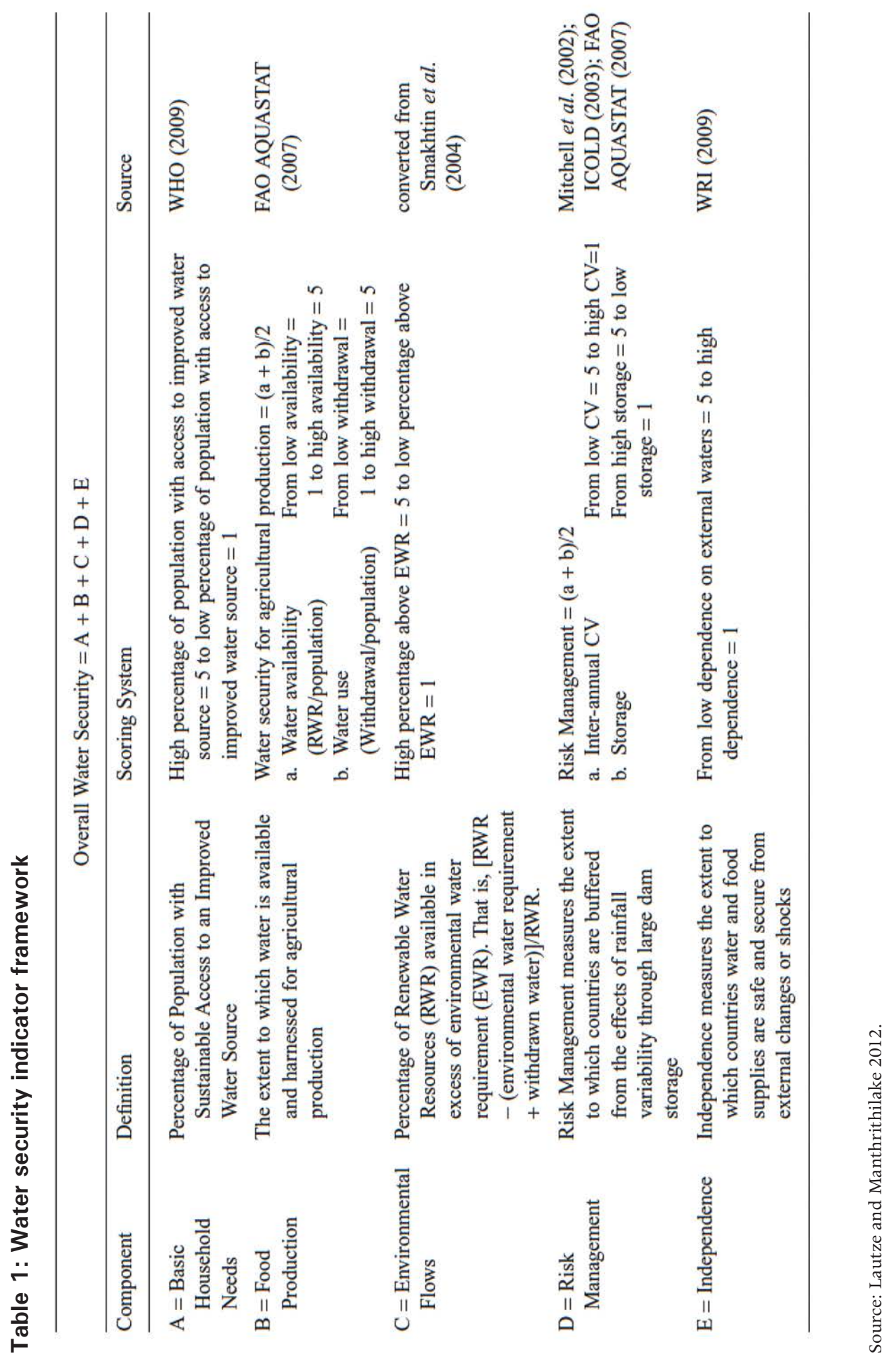




\section{Quantifying water security}

The paper identified five key components of water security and translated them into numerical indicators that were applied across the countries of the AsiaPacific. Based on several definitions of the concept, a conceptual framework was developed that contains the following components: basic needs, agricultural production, the environment, risk management and independence (Table 1). Using publicly accessible data, country scores in each component were developed and placed on a five-point scale. To generate a score for overall water security, results for each of the five components were summed, producing a 25-point scale. Just as five-point scales indicate the degree of water security achieved in individual components, the broader score on a 25-point scale indicates the degree of overall water security in a particular country.

\section{Results}

Comparing the strength of overall water security scores across countries reveals substantial dispersion (Figure 1), with scores ranging from very poor (less than ten) to very good (greater than 20). Noticeably, even in those countries that appear water secure, there still exist weak spots (Figure 2). For example, despite Australia's overall high level of water security, the specific component of risk management appears only mediocre, and Japan appears limited by its poor score in water security for the environment. While the results hold few surprises, if presented in countries where local knowledge may already exist on water sector strengths and weaknesses, a primary benefit of applying a water security framework such as this is to understand how water secure countries are in relation to one another. A secondary benefit, if the framework is reapplied in the future, is monitoring the rate and direction of change in water security to enable comparison over time. 


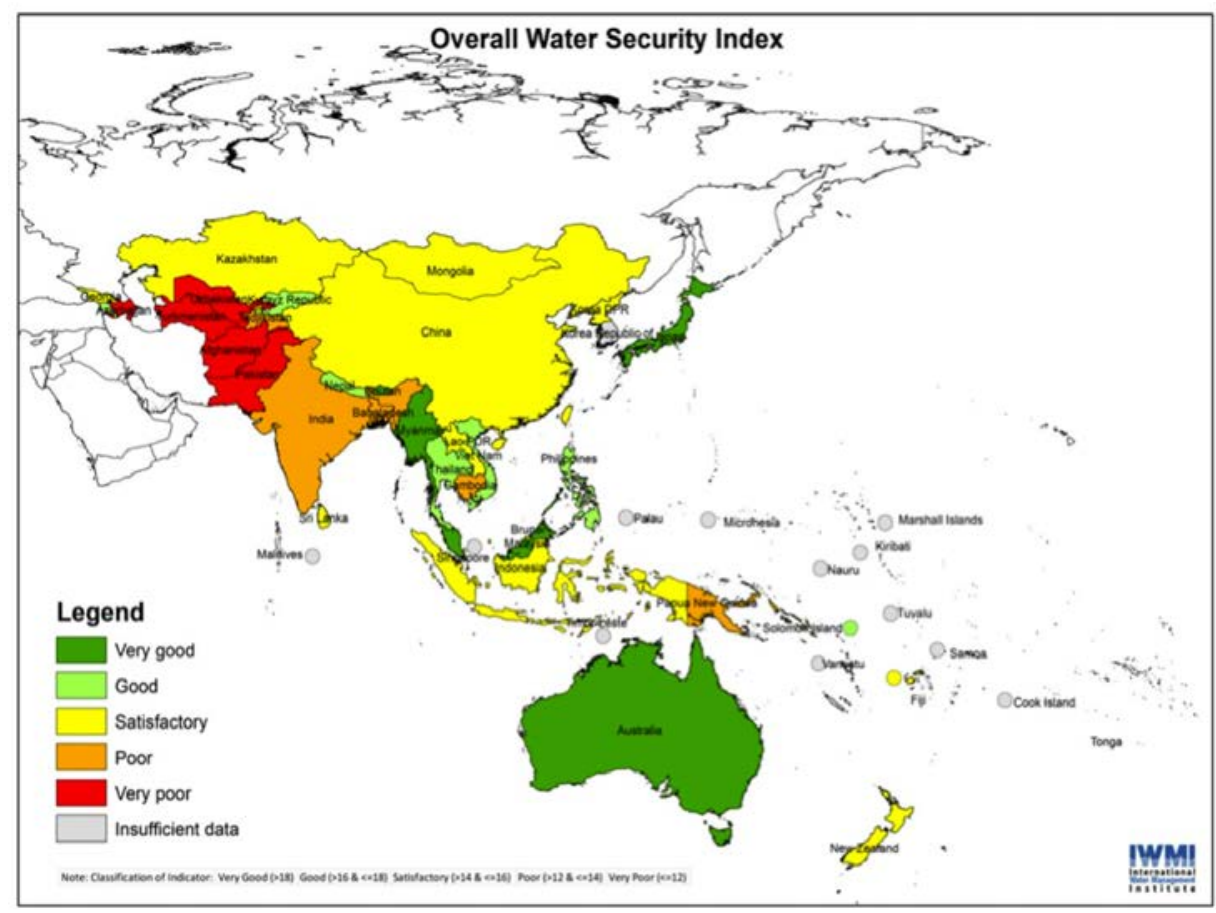

Figure 1: Overall water security index

Source: Lautze and Manthrithilake 2012. 


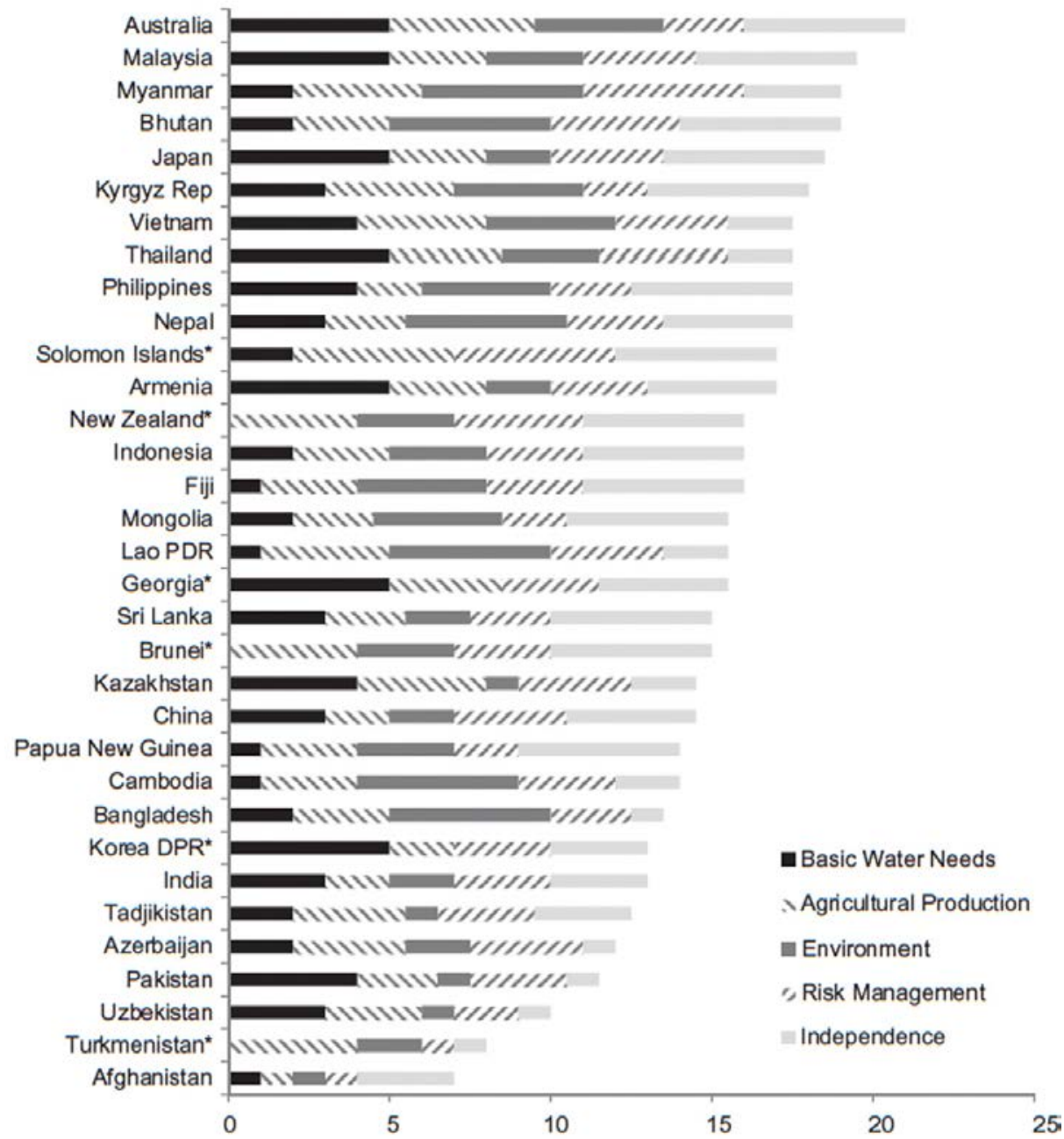

Figure 2: Water security in the Asia-Pacific, ordered from greatest to least water secure. *Indicates that data are available for only four of the five components. Countries with data for less than four components are not displayed

Source: Lautze and Manthrithilake 2012. 


\section{So what?}

An important goal of this paper was identifying some of the key issues inherent in assessing water security in order to spur more concrete discussion on what the concept truly means. One fundamental issue raised by the methods employed relates to assessment of relative versus absolute water security. More broadly, the development and application of the approach utilised in this paper has helped clarify the notion of water security, and prompts at least two overarching suggestions for understanding the meaning and practical utility of the concept.

A first suggestion for reaching a more common understanding of the concept is to move beyond qualitative definitions to make a list, or finite set of criteria, on which water security is determined and evaluated, as proposed in this paper. While the criteria utilised in this paper may not be perfect, it is believed they mark a valuable step toward arriving at a clear meaning of the concept.

A second suggestion is to clearly focus on the ends of water security - not the means to water security, and not the ends beyond water security. For example, conventional indicators in agricultural water management - such as water productivity and related sub-indicators of efficiency or yield per unit of evapotranspiration — could be proposed to measure water security. While improving water productivity is clearly a way to increase agricultural production and water security, it is simply one means and may not be essential. In areas of low water storage, for example, water storage augmentations may be far more important than productivity increases.

Related to ends beyond water security, water security can be considered essential to enabling a range of development outcomes, such as adequate food consumption, health status, economic opportunities, and environmental conservation. Achieving water security, however, is a necessary but insufficient condition for achieving security in these other areas: water security can imply that economies are insulated from droughts and floods, but it does insulate them from external shocks, such as global financial crises. Similarly, while water security could imply sufficient agricultural production to feed a community or country, it is not associated with the many other aspects of food security, such as timely crop selection, distribution and provision. As such, water security is but one contributor to the security of other areas, such as food and the environment, because their ultimate security relies on factors over and above those specific to water. 


\section{Final thoughts}

The approach utilised in this paper constitutes an initial effort to assess the central components of water security and identify some of the major issues in undertaking such an exercise. In terms of the issue posed at the outset about the added value of introducing the concept of water security, the results are mixed. While focusing on five priority issues related to water management is important, the benefits of bundling these five issues under the umbrella of a new paradigm are not immediately apparent. On the contrary, with so many other new concepts related to water permeating discourse (e.g., IWRM, water governance, hydropolitics), there may be confusion, scepticism, and even fatigue associated with introduction of another new term that is not concretely defined, yet which is supposed to comprise a panacea for water managers.

Dr Jonathan Lautze is a Researcher at the International Water Management Institute-Southern Africa office in Pretoria. He has been involved in a range of applied research and development projects focused on topics such as water governance, water security, transboundary water management, climate change and water, and water and health.

Dr Herath Manthrithilake has been involved in professional water sector work since the early 1970s. Currently, he serves as a Senior Researcher and Head of the Research Program of International Water Management Institute (IWMI) in Sri Lanka. This article is a summary version of Lautze and Manthrithilake, 2012, 'Water security: old concepts, new package, what value? Natural Resources Forum 36(2):76-87. For further details please contact email j.lautze@cgiar.org.

\section{References}

Briscoe, J., 2009. Harvard Water Initiative: Science technology and policy for water security. Available at: http://www.johnbriscoe.seas.harvard.edu/ research/Harvard $\% 20$ University $\% 20$ Water $\% 20$ Security $\% 20$ Initiative $\% 20$ 20090609.pdf.

International Commission on Large Dams (ICOLD), 2003. World Register of Large Dams. Paris.

Food and Agriculture Organisation (FAO) AQUASTAT, 2007. Website of the FAO Information System on Water and Agriculture. Available at: http://www.fao. org/nr/water/aquastat/main/index.stm.

Grey, D. and Sadoff, C., 2007. 'Sink or swim? Water security for growth and development', Water Policy 9:545-71. 
Global Water: Issues and Insights

Lautze, J. and Manthrithilake, H., 2012. 'Water security: old concepts, new package, what value?', Natural Resources Forum 36(2):76-87.

Liu, B., Mei, X., Li, Yu and Yang, Y., 2007. 'The connotation and extension of agricultural water resources security', Agricultural Sciences in China 6(1):11-16.

Mitchell, T.D., Hulme, M. and New, M., 2002. 'Climate data for political areas', Area 34(1):109-12.

Smakhtin, V., Revenga, C. and Döll, P., 2004. A pilot global assessment of environmental water requirements and scarcity', Water International 29(3):307-17.

WaterLink, 2010. 'Nile Basin initiative deadlock'. 6 July. Available at: http://www. waterlink-international.com/news/id1230-Nile_Basin_Initiative_Deadlock. html.

World Health Organisation (WHO), 2009. 'World health statistics 2009'. Available at: http://www.who.int/whosis/whostat/2009/en/index.html.

World Resources Initiative (WRI), 2009. Earthtrends environmental information searchable database. Available from: http://earthtrends.wri.org/\#. 
This text taken from Global Water: Issues and Insights by R. Quentin Grafton, Paul Wyrwoll, Chris White and David Allendes, published May 2014 by ANU Press, The Australian National University, Canberra, Australia. 